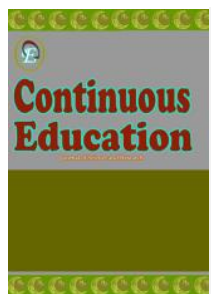

Continuous Education : Journal of Science and Research

Volume 2, Issue 1, March 2021

http://pusdikra-publishing.com/index.php/josr/home-free

\title{
Pengembangan Karier Guru Di Pesantren Darul Ihsan Hamparan Perak Deli \\ Serdang
}

Agus Salim Salabi

IAIN Lhokseumawe, Indonesia

Corresponding Author: @ salim.salabi@gmail.com

\author{
ARTICLE INFO \\ Article history: \\ Received \\ 01 March 2021 \\ Revised \\ 10 March 2021 \\ Accepted \\ 14 March 2021
}

\begin{tabular}{l} 
ABSTRACT \\
Career development is the process of identifying the employee's career \\
potential and material and applying the right ways to develop this \\
potential. The teacher career development process at Pesantrren Darul \\
Ihsan begins with the implementation of monitoring and evaluation of \\
teacher performance. This study aims to analyze and find: 1) the concept \\
of teacher career development at Pesantren Darul Ihsan Hamparan Perak \\
Deli Serdang, and 2) the types of teacher career development at Pesantren \\
Darul Ihsan Hamparan Perak Deli Serdang. The two focuses are studied \\
with the theoretical approach of career management, human resource \\
management, and human resource development as well as several other \\
relevant theories. This study uses a qualitative research model with a case \\
study approach. The data collection technique is by using semi-structured \\
interviews and document studies. Furthermore, after the data has been \\
collected, it is analyzed using several steps: data condensation, data \\
display and conclusion, drawing and verification. The results of this \\
study: 1) Teacher career development is carried out in the form of a \\
personal and career advancement plan, as well as monitoring and \\
evaluation which have implications for: (a) repositioning, (b) dismissal, c) \\
resignation, d) retire. 2) Types of teacher career development that are: \\
short courses, study assignments or study permit, and in house training \\
(IHT). Meanwhile, pesantren support for the career development of \\
teachers is conditional and unconditional. \\
Teacher, Career, Development, Pesantren \\
\hline Agus Salim Salabi. (2021). Pengembangan Karier Guru Di Pesantren Darul \\
Ihsan Hamparan Perak Deli Serdang. Journal Continuous Education, 2(1). \\
1-16. Doi, 10.51178/ce.v2i1.170
\end{tabular}

\section{PENDAHULUAN}

Setiap pemimpin dalam sebuah organisasi selalu berupaya memposisikan para karyawannya pada tempat kerja yang sesuai dengan bidang keahliannya. Upaya ini biasa disebut sebagai pertimbangan karier. Pertimbangan karier dalam organisasi, tentu berkaitan dengan pengembangan karier yang bukan saja menjadi tanggung jawab pimpinan organisasi, namun juga menjadi tanggung jawab tiap individu. Sebagian besar manfaat dari proses pengembangan karier tantu akan dirasakan oleh individu itu sendiri dalam menuju kesuksesannya. Di lain pihak, organisasi juga menerima manfaat dari 
proses pengembangan karier anggotanya dalam bentuk peningkatan output secara langsung (Zaini \& Syafaruddin, 2020).

(Simonsen, 1997) menyatakan, bahwa pengembangan karier di dalam organisasi menjadi tanggung jawab bersama antara individu dan organisasi sebagai proses penyesuaian antara karyawan dan pekerjaan dalam rangka memanfaatkan segala sumber yang ada secara optimal. Pengembangan karier sebagai proses berkelanjutan, harus didukung oleh organisasi dan harus diperkuat serta ditingkatkan oleh sumber daya manusia itu sendiri.

Secara sederhana, pengembangan karier dapat dikatakan sebagai upaya peningkatan yang dilakukan untuk menyelaraskan kemampuan seseorang dengan perencanaan dan manajemen karier. Adapun perencanaan karier merupakan proses pemilihan tujuan karier dan pola karier yang akan dipergunakan oleh seseorang dalam upaya pencapaian tujuan karier yang bertalian. Sementara manajemen karier adalah upaya yang dilakukan organisasi dalam rangka menetapkan karier anggotanya.

Adapun hal-hal yang dapat dilakukan sebagai penunjang dalam mengembangkan karier seseorang adalah dengan membuat perencanaan untuk dapat mencapai jenjang karier yang diharapkan, seperti meningkatkan keterampilan, pengetahuan, motivasi, dan personalitas atau karakteristik yang dimiliki individu untuk mencapai tujuan dari kariernya tersebut (Dessler, 1997).

Meskipun pengembangan karier secara umum berdasarkan prestasi, masa kerja, dam kesempatan, namun tidak jarang ditemukan, bahwa upaya pengembangan karier bagi guru di peasantren-pesantren sebagai lembaga pendidikan Islam belum memperoleh porsi yang sesuai. Hal ini terlihat dalam pelaksanaan pengembangan karier yang masih mengacu pada kedekatan personal antara bawahan dan pimpinan dan penilaian subjektif yang dapat menghasilkan keputusan atas dasar like or dislike (suka atau tidak suka). Sehingga seorang guru, meskipun memiliki kepantasan untuk meningkatkan karier karena prestasi dan masa kerjanya yang layak, menjadi terhambat dikarenakan atasannya kurang menyukai kepribadiannya. Di lain pihak, minimnya pendanaan yang dimiliki pesantren juga menjadi faktor penghambat terlaksananya pengembangan karier para gurunya.

Salah satu lembaga pendidikan Islam yang sangat memperhatikan pengembangan karier guru adalah Pesantren Darul Ihsan yang terletak di Kecamatan Hamparan Perak Kabupten Deli Serdang Sumatera Utara. Pesantren ini dipimpin oleh Muhammad Safri, M.M. yang menjabat sebagai direktur pesantren (mudìr al-ma'had) sejak tahun 2018. 
Pengembangan karier guru di Pesantren Darul Ihsan menjadi kajian penting dalam rangka memaparkan "konsep pengembangan karier guru" dan "jenis-jenis pengembangan karier guru yang dapat diterapkan di pesantren". Hal ini tentu menjadi pengaruh besar terhadap kepuasan kerja dan meningkatnya loyalitas terhadap lembaga di mana para guru mengabdikan diri mereka dalam melaksanakan pembelajaran dan pendidikan serta mengurangi tingkat perputaran (turn-over) para guru yang tentu akan berpengaruh negatif terhadap proses belajar mengajar.

\section{METODE PENELITIAN}

Jenis penelitian ini adalah kualitatif dengan pendekatan studi kasus. Adapun teknik pengumpulan data dilakukan melalui wawancara semiterstruktur dan studi dokumen. Pengumpulan data dalam penelitian ini juga tidak terlepas dari kajian pada buku-buku, jurnal, dan hasil penelitian terdahulu yang relevan dengan tema penelitian, di antaranya literatur tentang manajemen karier, manajemen sumber daya manusia, dan pengembangan sumber daya manusia. Selanjutnya, dilakukan pula analisis data dengan menggunakan beberapa langkah yang dikemukakan (Huberman \& J, 2014), yaitu: pengumpulan data, kondensasi data, menyajikan data, dan menarik kesimpulan atau verifikasi.

\section{HASIL PENELITIAN DAN PEMBAHASAN}

\section{Manajemen Karier}

(Greenhaus et al., 2000) Menyoroti urutan kegiatan dalam manajemen karier, di mana model ini telah ditata dalam lingkungan yang sebagian besar dipengaruhi oleh informasi, peluang, dan dukungan dari pendidikan, keluarga, pekerjaan, dan lembaga kemasyarakatan lainnya. Model ini merupakan pola kegiatan yang akan mengarah pada hasil yang diinginkan berdasarkan asumsi, bahwa individu tidak diharuskan untuk mengikuti urutan yang sama, individu dapat melaksanakan secara acak atau mengesampingkan kegiatan tertentu. Adapun Model manajemen karier mencakup langkah-langkah berikut:

1. Eksplorasi karier; yaitu mengumpulkan informasi tentang karier dan lingkungan.

2. Kesadaran diri dan lingkungan; dengan mengetahui kekuatan dan kelemahan individu serta nilai-nilai.

3. Penetapan sasaran; adalah merancang harapan kerja dan nilai-nilai pribadi serta aspirasi tujuan karier.

4. Pengembangan strategi; upaya mengidentifikasi target, kebutuhan untuk mengembangkan strategi dalam mencapai tujuan. 
5. Implementasi Strategi; pada langkah ini kemajuan menuju tujuan dimulai dan lapangan praktis yang dialami sudah ditemui.

6. Umpan balik dari sumber pekerjaan dan non-kerja; selain pengalaman pribadi, tiap individu membutuhkan umpan balik dari sumber pekerjaan.

7. Karier appraisal; berdasarkan umpan balik dan pengalaman pribadi terkait karier, kegiatan dievaluasi. Hal ini dilakukan untuk mengetahui apakah kemajuan menuju tujuan yang ditetapkan sedang terjadi atau tidak.

(Simamora, 2004) Menyatakan, bahwa: "Manajemen karier adalah proses bekelanjutan dari penyiapan, penerapan dan pemantauan rencana karier yang dilakukan oleh individu itu sendiri atau seiring dengan sistem karier organisasi." Secara luas, manajemen karier meliputi seluruh kegiatan yang berkenaan dengan pekerjaan pegawai. Kegiatan ini dimulai dari proses penarikan (rekrutmen) pegawai, penempatan pegawai, pengembangan pegawai, dan berakhir pada pemberhentian pegawai. Manajemen karier adalah proses pengelolaan karier pegawai yang meliputi tahapan kegiatan perencanaan karier, pengembangan dan konseling karier, serta pengambilan keputusan karier.

Manajemen karier melibatkan semua pihak termasuk pegawai yang bersangkutan dengan unit tempat si pegawai bekerja, dan organisasi secara keseluruhan. Oleh karena itu manajemen karier mencakup area kegiatan yang sangat luas. Dalam manajemen karier, (Stoner \& Charles Wankel, 1986) menyimpulkan sebuah proses staffing dalam organisasi sebagai berikut:

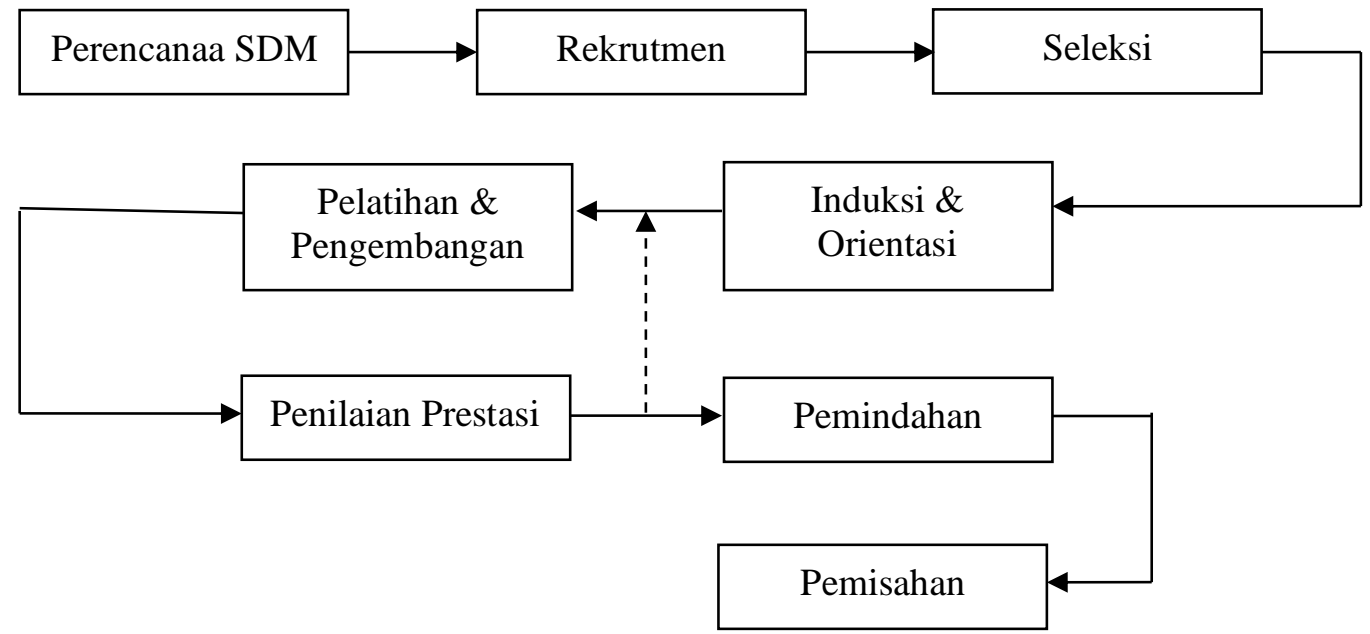

Gambar: Proses Staffing dalam Organisasi Sumber: Stoner dan Wankel (1986) 


\section{Perencanaan SDM}

Dirancang untuk menjamin bahwa kebutuhan organisasi akan pegawai dipenuhi secara tetap dan tepat. Perancanaan dapat dilakukan melalui analisis: a) faktor-faktor dari alam seperti keterampilan yang dibutuhkan sekarang dan yang akan datang, dan b) faktor-faktor di lingkungan luar seperti pasar tenaga kerja.

2. Rekrutmen

Biasanya para calon diperoleh melalui iklan pada surat kabar atau media elektronik lain, biro tenaga kerja, dari mulut ke mulut, kunjungan ke kampus-kampus atau kursus-kursus.

\section{Seleksi}

Kegiatan ini merupakan upaya pengevaluasian dan pemilihan di antara para calon pegawai melalui formulir lamaran, tes keterampilan, wawancara, dan pemeriksaan referensi.

4. Induksi dan orientasi

Tahapan ini dirancang untuk membantu orang-orang yang terpilih agar bisa menyesuaikan diri dengan baik dalam organisasi. Para pendatang baru diperkenalkan kepada rekan kerja, taanggung jawab kerja, kebijakan dan tujuan organisasi, dan lain sebagainya.

5. Pelatihan dan pengembangan

Untuk meningkatkan kemampuan para pegawai agar dapat memberikan sumbangan kepada efektivitas organisasi, maka pelatihan dirancang sehingga keterampilan pada pekerjaan dapat meningkat. Adapun pengembangan dirancang untuk mendidik pegawai melebihi persyaratan posisi mereka sekarang sehingga individu akan siap dipromosikan.

6. Penilaian prestasi

Tahapan ini dilakukan untuk membandingkan prestasi kerja individu dengan standar atau sasaran yang dikembangkan untuk posisi individu tersebut. Jika prestasi individu tinggi, maka akan diberi imbalan (misalnya bonus atau tugas-tugas yang lebih menantang). Jika prestasi rendah, maka akan diambil tindakan perbaikan (misalnya pelatihan tambahan) untuk mengembalikan prestasi ke arah sesuai dengan standar. 
7. Pemindahan

Pemindahan dapat diartikan sebagai pergeseran seseorang dari jabatan, tingkatan dalam organisasi. Jenis-jenis pemindahan yang umum adalah; a) promosi, yaitu pergeseran ke posisi yang lebih tinggi, b) lateral, yaitu pergeseran dari satu posisi ke posisi yang lain yang sama, c) demosi, yaitu pergeseran ke posisi yang lebih rendah.

8. Pemisahan

Pemisahan dapat berupa pengunduran diri, pemberhentian sementara, pemecatan, atau pensiun.

\section{Pengembangan Karier}

Dalam sebuah organisasi, pengembangan karier semestinya juga bersinggungan dengan manajemen karier, di mana (Mabey \& Thomson, 1994) menyarankan adanya komitmen terhadap proses manajemen karier, kebijakan yang jelas dan proses yang sistematis dalam memastikan keadilan dan efisiensi sejauh mana individu memiliki kebebasan pilihan dalam promosi pekerjaan." Pilihan dalam promosi pekerjaan yang ditandai dengan perkembangan dan kemajuan, biasa juga disebut dengan karier.

Karier menurut (Simamora, 2004), adalah urutan aktivitas-aktivitas yang berhubungan dengan pekerjaan dan perilaku, nilai-nilai, dan aspirasi seseorang selama rentang hidup orang tersebut. Sementara Hani Handoko dalam (Danang Sunyoto, 2012) menerangkan, bahwa pengertian karier ada tiga yaitu:

1. Karier sebagai suatu urutan promosi atau pemindahan (transfer) lateral ke jabatan-jabatan yang lebih menuntut tanggung jawab atau lokasilokasi yang lebih baik dalam menyilang hierarki hubungan kerja.

2. Karier sebagai penunjuk pekerjaan-pekerjaan yang membentuk suatu pola kemajuan sistematik yang jelas.

3. Karier sebagai sejarah pekerjaan seseorang atau serangkaian posisi yang dipegangnya selama kehidupan kerja.

Berdasarkan pengertian-pengertian karier di atas dapat dikatakan, bahwa karier merupakan serangkaian perubahan sikap, nilai, dan perilaku serta motivasi yang terjadi pada setiap individu selama rentang waktu kehidupannya untuk menemukan secara jelas keahlian, tujuan karier, kebutuhan untuk pengembangan, merencanakan tujuan karier, dan secara kontinu mengevaluasi, merevisi serta meningkatkan rancangannya. Karier juga 
merupakan suatu proses kemitraan interaksi dalam tahapan dan kerja sama antara organisasi dan individu itu sendiri.

Adapun pengembangan karier adalah proses mengidentifikasi potensi karier pegawai dan materi serta menerapkan cara-cara yang tepat untuk mengembangkan potensi tersebut. Secara umum proses pengembangan karier dimulai dengan mengevaluasi kinerja karyawan di mana proses ini juga lazim disebut sebagai penilaian kerja (Danang Sunyoto, 2012; Zaini, 2019). Pengembangan karier menurut (Greenhaus et al., 2000) adalah "proses berkelanjutan" yang mana individu dapat berkembang melalui serangkaian tahapan, yang masing-masing dicirikan oleh serangkaian masalah, tema, dan tugas yang relatif unik. Dari sudut pandang organisasi, pengembangan karier dan perencanaan karier dalam organisasi sebagian besar berkaitan dengan pelacakan jalur dan pengembangkan tangga karier. (Mabey \& Thomson, 1994) berkomentar, jika organisasi tidak mempertimbangkan karier dan perencanaan suksesi, maka akan menjadi sulit bagi individu untuk mengejar rencana karier mereka.

Pengembangan karier sangat penting bagi suatu organisasi, karena karier merupakan kebutuhan yang harus terus dikembangkan dalam diri seorang karyawan sehingga mampu memotivasi pegawai untuk meningkatkan kinerjanya. Dengan meningkatnya kinerja seorang karyawan dalam sebuah organisasi, mengindikasikan adanya peningkatan dan pengembangan sumber daya manusia yang tentunya memerlukan perencanaan sumber daya manusia.

Menurut (Rivai, 2013), pengembangan karier adalah proses peningkatan kemampuan kerja individu dalam rangka mencapai karier yang diinginkan dan merupakan suatu pendekatan-pendekatan kegiatan secara formal untuk peningkatan-peningkatan atau perbaikan-perbaikan, pertumbuhan, kepuasan kerja, menambah pengetahuan dan kemampuan individu.

Dapat disimpulkan, bahwa pengembangan karier merupakan peningkatan-peningkatan pribadi yang dilakukan seseorang untuk mencapai suatu rencana karier. Fokus pengembangan karier adalah peningkatan kemampuan mental yang terjadi seiring penambahan usia sumber daya manusia atau pegawai.

Adapun pengembangan karier guru di lembaga pendidikan Negeri biasanya terdiri dari tiga ranah (silabus.web.id), yaitu: 
1) Penugasan guru

Penugasan guru adalah pelaksanaan kegiatan pokok yang mencakup: merencanakan pembelajaran, melaksanakan pembelajaran, menilai hasil pembelajaran, membimbing dan melatih peserta didik, dan melaksanakan tugas tambahan yang melekat pada pelaksanaan kegiatan pokok sesuai dengan beban kerja guru.

2) Kenaikan pangkat

Kenaikan pangkat dapat dilakukan melalui dua jalur; Pertama, kenaikan pangkat dengan sistem pengumpulan angka kredit. Kedua, kenaikan pangkat karena prestasi kerja atau dedikasi yang luar biasa. Kenaikan pangkat dan jabatan fungsional guru dengan sistem pengumpulan angka kredit dalam rangka pengembangan karir merupakan gabungan dari angka kredit unsur utama dan penunjang ditetapkan sesuai dengan Permen PAN dan RB Nomor 16 Tahun 2009. Tugas-tugas guru yang dapat dinilai dengan angka kredit untuk keperluan kenaikan pangkat dan/atau jabatan fungsional guru mencakup unsur utama dan unsur penunjang. Unsur utama kegiatan yang dapat dinilai sebagai angka kredit dalam kenaikan pangkat guru terdiri atas: a) pendidikan, b) pembelajaran/pembimbingan dan tugas tambahan dan atau tugas lain yang relevan dengan fungsi sekolah/madrasah, dan c) pengembangan keprofesian berkelanjutan (PKB).

3) Promosi, dapat berupa penugasan sebagai guru pembina, guru inti, instruktur, wakil kepala sekolah, kepala sekolah, pengawas sekolah, dan sebagainya. Kegiatan promosi ini harus didasari atas pertimbangan prestasi dan dedikasi tertentu yang dimiliki oleh guru. Hal ini senada dengan Peraturan Pemerintah No. 74 tentang Guru yang mengamanatkan, bahwa dalam melaksanakan tugas keprofesian, guru berhak mendapatkan promosi sesuai dengan tugas dan prestasi kerja. Promosi dimaksud meliputi kenaikan pangkat dan/atau kenaikan jenjang jabatan fungsional. Sementara itu, kenaikan pangkat dan promosi bagi guru-guru yang berdedikasi di lembaga pendidikan swasta, harus didasari atas pertimbangan prestasi dan dedikasi tertentu yang dimiliki oleh guru. 


\section{Fakor-Faktor yang Mempengaruhi Pengembangan Karier}

Menurut (Rivai, 2013) faktor-faktor yang mempengaruhi pengembangan karier adalah sebagai berikut:

1. Prestasi kerja (job performance); Hal ini merupakan komponen yang paling penting untuk peningkatan dan pengembangan karier seorang karyawan. Dengan mengetahui hasil atas kinerjanya, maka karyawan dapat mengukur kesempatannya terhadap pengembangan karier. Asumsi terhadap kinerja yang baik akan melandasi seluruh aktivitas pengembangan karier. Ketika kinerja di bawah standar maka dengan mengabaikan upaya-upaya ke arah pengembangan karier pun biasanya tujuan karier yang paling sederhana pun tidak dapat dicapai.

2. Eksposur; Manajer atau atasan memperoleh pengenalan ini melalui kinerja, dan prestasi karyawan, laporan tertulis, presentasi lisan, pekerjaan komite dan jam-jam yang dihabiskan.

3. Jaringan kerja; Jaringan kerja berarti perolehan eksposur di luar perusahaan. Mencakup kontak pribadi dan profesional. Jaringan tersebut akan sangat bermanfaat bagi karyawan terutama dalam pengembangan kariernya.

4. Kesetiaan terhadap organisasi; Level loyalitas yang rendah merupakan hal yang umum terjadi di kalangan lulusan perguruan tinggi terkini yang disebabkan ekspektasi terlalu tinggi pada perusahaan tempatnya bekerja pertama kali sehingga seringkali menimbulkan kekecewaan. Untuk mengatasi hal ini sekaligus mengurangi tingkat keluarnya karyawan (turn-over) biasanya perusahaan "membeli" loyalitas karyawan dengan gaji, tunjangan yang tinggi, melakukan praktikpraktik SDM yang efektif seperti perencanaan dan pengembangan karier.

5. Pembimbing dan sponsor; Adanya pembimbing dan sponsor akan membantu karyawan dalam mengembangkan kariernya. Pembimbing akan memberikan nasihat-nasihat atau saran-saran kepada karyawan dalam upaya pengembangan kariernya, pembimbing berasal dari internal perusahaan. Adapun sponsor adalah seseorang di dalam perusahaan yang menciptakan kesempatan untuk pengembangan kariernya.

6. Peluang untuk tumbuh; Karyawan hendaknya diberikan kesempatan 
untuk meningkatkan kemampuannya, misalnya melalui pelatihanpelatihan, kursus, dan melanjutkan pendidikannya.

\section{Manfaat Pengembangan Karier}

Pengembangan karier bagi karyawan sangat diharapkan karena bermanfaat untuk memotivasi mereka dalam bekerja dengan baik. Manfaat pengembangan karier tentunya dapat meningkatkan kepuasan karyawan dan meningkatkan efektivitas organisasi. (Rizka, 2013; Sadili Samsudin, 2006) menjelaskan, bahwa pengembangan karier pada dasarnya bermanfaat dalam (a) meningkatkan kemampuan karyawan yang dapat dilakukan melalui pendidikan dan pelatihan, dan (b) meningkatkan suplai karyawan yang berkemampuan, di mana karyawan yang lebih tinggi kemampuannya akan bertambah dari sebelumnya sehingga memudahkan pihak pimpinan untuk menempatkan karyawann dalam pekerjaan yang lebih tepat.

Pengembangan karier bukan merupakan tanggung jawab pegawai saja tetapi merupakan bagian dari tanggung jawab organisasi di mana pegawai itu bekerja. Untuk melakukan pengembangan karier pegawai di sebuah instansi selain membuat perencaanaan karier pegawai, manajemen karier juga harus diperhatikan oleh organisasi di mana pegawai tersebut bekerja.

Pengembangan Karier Guru di Pesantren Darul Ihsan Hamparan Perak Deli Serdang Sumatera Utara

\section{Pengembangan Karier dan Jenis Pengembangan Karier}

Secara prinsip, Pesantren Darul Ihsan mendukung setiap upaya pengembangan diri dan profesi (personal and professional development) bagi setiap pegawainya, di mana masih banyak pondok pesantren terutama di lingkungan Kabupaten Deli Serdang Sumatera Utara yang belum menempatkan aspek pengembangan karier para karyawannya (pendidik/ustaz dan tenaga kependidikan) sebagai hal yang urgen.

Upaya pengembangan diri, profesi, dan karier para guru Darul Ihsan dilakukan atas inisiatif individu dan pimpinan pesantren (mudìr al-ma'had). Pengembangan diri, profesi, dan karier dimaksudkan sebagai upaya meningkatkan kesejahteraan dan ketenangan dalam kehidupan pribadi para guru, serta kecakapan dan kemahiran dalam melaksanakan pekerjaan yang bersangkutan.

Pesantren Darul Ihsan mendukung upaya program pengembangan diri dan profesi dalam bentuk program peningkatan karier dan pengembangan diri 
(personal and career advancement plan) dengan skema sebagai berikut:

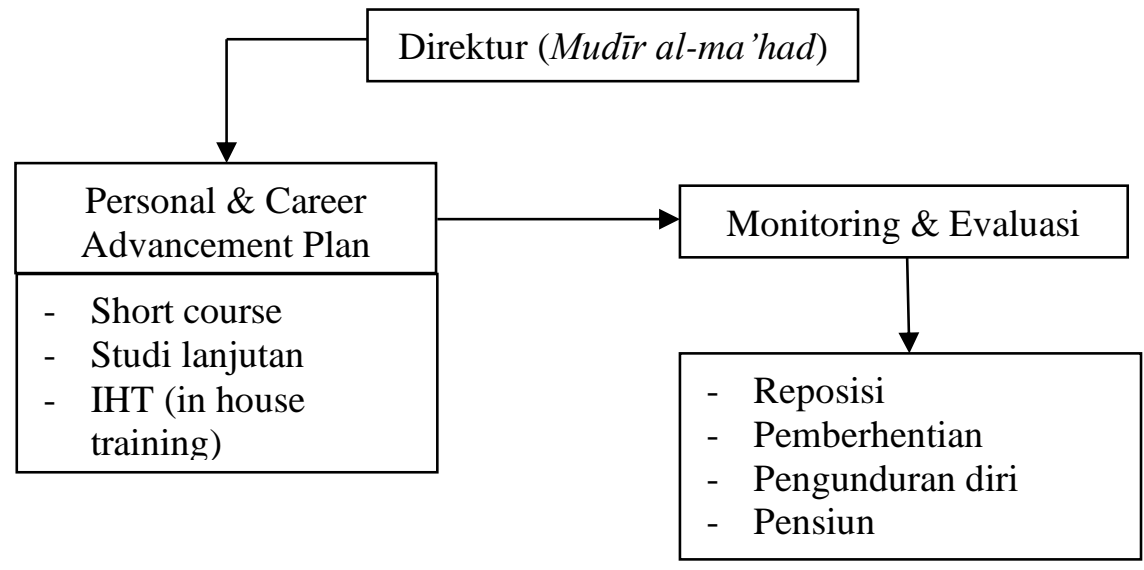

Gambar: Skema Peningkatan Karier dan Pengembangan Diri Sumber: Hasil Penelitian

Untuk mendukung terlaksananya program pengembangan diri dan karier di atas, pesantren memfasilitasi berbagai program dan aktivitas yang menunjang, di antaranya: pelatihan dan pengembangan, seminar, short course, studi lanjutan, dan sebagainya, yang disesuaikan dengan kemampuan finansial pesantren, dengan memperhatikan bakat, minat, kompetensi, dan kinerja yang ditunjukkan oleh para guru. Dukungan pesantren bagi guru dalam hal pengembangan diri dan profesi bersifat bersyarat dan tanpa syarat.

Dukungan bersifat bersyarat diberikan dalam hal dan berimplikasi sebagai berikut:

a. Kegiatan tersebut diikuti oleh guru atas inisiatif atau perintah mudir al-ma'had dan pembiayaannya ditanggung sepenuhnya oleh pesantren.

b. Kegiatan tersebut bertujuan memperoleh pengakuan kecakapan profesional (sertifikasi/ijazah), bersifat studi lanjut (meneruskan studi ke jenjang/strata akademik yang lebih tinggi; S1/S2/S3), atau bersifat uji kompetensi profesi yang berkonsekuensi diperolehnya gelar profesi khusus (certified professional) bagi guru yang mengikutinya.

c. Kesempatan mengikuti kegiatan tersebut diberikan kepada guru Pesantren Darul Ihsan yang telah memiliki masa kerja sekurangkurangnya 3 (tiga) tahun dan menunjukkan kinerja yang memenuhi standar yang ditetapkan oleh pesantren. 
d. Guru yang telah selesai mengikuti kegiatan/program pengembangan diri yang bersifat bersyarat diwajibkan menyimpan salinan materi pelatihan/pengembangan yang telah diperolehnya kepada pihak pesantren dan mempresentasikan hasil-hasil pelatihan/pengembangan tersebut.

e. Guru yang telah mengikuti studi lanjut atau uji kompetensi profesi dan/atau pelatihan/pengembangan yang bersifat bersyarat dan kemudian berhenti atas kemauan sendiri sebelum berakhir masa kerjanya di pesantren, diwajibkan mengganti biaya studi lanjut atau uji kompetensi profesi dan/atau pelatihan/pengembangan yang telah diikutinya tersebut.

f. Jika guru bermaksud mengikuti studi lanjut (tugas/izin belajar ke jenjang S1/S2/S3) belum memenuhi syarat minimal masa kerja sebagaimana tersebut di atas namun memiliki kemampuan finansial untuk mengikuti studi lanjut, maka pesantren dapat memberikan kesempatan kepadanya untuk menunaikan maksudnya tersebut dengan ketentuan:

1) Seluruh biaya studi lanjut ditanggung oleh guru yang bersangkutan.

2) Jika pelaksanaan studi lanjut memiliki konsekuensi tiadanya waktu mengajar di pesantren, maka guru yang bersangkutan wajib mengajukan permohonan cuti di luar tanggungan kepada pesantren guna mengikuti studi lanjut tersebut dengan ketentuan bahwa selama masa cuti di luar tanggungan, pesantren tidak berkewajiban memberikan kompensasi apapun.

3) Jika pelaksanaan studi lanjut memiliki konsekuensi berkurangnya waktu mengajar di pesantren, maka guru yang bersangkutan wajib mengajukan permohonan bekerja paruh waktu kepada pesantren guna mengikuti studi lanjut tersebut dengan ketentuan bahwa selama masa bekerja paruh waktu tersebut kompensasi yang diterima oleh guru yang bersangkutan akan disesuaikan nilainya secara proporsional (mengacu pada jumlah jam mengajar). Dalam hal seorang guru ditugaskan oleh pesantren untuk mengikuti studi lanjut (tugas/izin belajar ke jenjang S1/S2/S3) atas biaya dari pesantren, maka ketentuan yang berlaku terhadap pegawai 
tersebut adalah sebagai: (a) pesantren berwenang menentukan jumlah hari minimal bagi guru untuk mengajar, (b) pesantren akan memberikan kompensasi (penerimaan bulanan) bagi guru bersangkutan sesuai jumlah jam mengajar, dan (c) setelah menyelesaikan studi lanjut pegawai wajib bekerja untuk pesantren, sekurang-kurangnya 'dua kali' masa studi lanjut ditempuh.

Adapun dukungan bersifat tanpa syarat diberikan dalam hal dan berimplikasi sebagai berikut:

a. Kegiatan tersebut diikuti atas inisiatif guru yang disetujui oleh mudìr al-ma'had dan pembiayaannya ditanggung oleh pesantren dan/atau sebagiannya ditanggung oleh guru.

b. Guru yang telah selesai mengikuti kegiatan/program pengembangan diri dan profesi yang bersifat tanpa syarat diwajibkan mempresentasikan hasil-hasil pelatihan/pengembangan tersebut.

c. Selama guru mengikuti kegiatan/program pengembangan diri dan profesi yang bersifat tanpa syarat, pesantren tetap memberikan hakhaknya sesuai ketentuan yang berlaku untuknya.

d. Guru yang telah mengikuti kegiatan/program pengembangan diri dan profesi yang bersifat tanpa syarat dan kemudian berhenti atas kemauan sendiri sebelum berakhirnya masa kerjanya di pesantren, tidak diwajibkan mengganti biaya kegiatan/program pengembangan diri, profesi, pelatihan/pengembangan yang telah diikutinya tersebut.

\section{Monitoring dan Evaluasi dalam Pengembangan Karier}

Untuk menjamin kelangsungan kualitas program pendidikan Pesantren Darul Ihsan, perlu dilakukan kegiatan pemantauan dan evaluasi secara teratur terhadap:

a. Upaya yang dilakukan para guru (asātizah) yang dapat mendorong kemandirian siswa dalam belajar, menumbuhkan sikap dan persepsi positif terhadap kegiatan belajar melalui perkembangan belajar santri dan prestasi belajar santri.

b. Hubungan komunikasi yang dibangun antara asātizah dan santri serta pihak lain yang diyakini dapat mempengaruhi prestasi pengetahuan dan sikap santri. 
c. Hubungan komunikasi profesional antara pimpinan pesantren, kepala madrasah, asātiz̧ah (pendidik), dan tenaga kependidikan.

Adapun implikasi dari monitoring dan evaluasi adalah; reposisi (penempatan guru pada posisi/jabatan yang berbeda), pemberhentian (sebelum masa tugas selesai dikarenakan kualifikasi guru yang bersangkutan tidak lagi sesuai dengan harapan), pengunduran diri (atas kemauan sendiri), dan pensiun (tidak bekerja lagi karena masa tugasnya sudah selesai).

Hal lain yang dilakukan dalam rangka monitoring dan evaluasi adalah "reselection (seleksi ulang)" sebagaimana yang disampaikan oleh Ustaz Muhammad Syafri selaku pimpinan pesantren (mudì al-ma'had) sebagai berikut:

“Dalam rangka penyegaran dan revitallisasi pendidik dan tenga kependidikan, saya memandang perlu untuk melakukan seleksi ulang dengan cara memberikan surat pemutusan hubungan kerja kepada seluruh karyawan. Dengan menimbang hasil monitoring dan evaluasi selama satu tahun terakhir, selanjutnya setiap PTK yang dianggap layak (loyal, disiplin, dan berintegritas) mendapat panggilan dan tawaran untuk kembali ke Darul Ihsan. Sementara bagi PTK yang dianggap tidak layak (tentunya mengacu pada hasil monev dan musyarah pimpinan), tidak dilayangkan pemanggilan atau penawran bergabung kembali alias putus hubungan kerja."

Adapun implikasi dari hasil monitoring dan evaluasi yang dilakukan mudì al-ma'had dalam rangka kenyamanan karier para guru Pesantren Darul Ihsan Hamparan Perak Deli serdang adalah:

a. Memaksimalkan jam mengajar para ustaz (tidak kurang dari 24 jam pelajaran). Dengan bertambahnya jam mengajar, maka secara otomatis akan bertambah pula pendapatan/gaji yang akan diterima. Dan bagi guru yang bersertifikasi akan menjamin keberlangsungan penerimaan tunjangan sertifikasi karena syarat untuk memperoleh sertifikasi guru telah terpenuhi.

b. Melakukan reposisi atau penambahan jabatan; dari hasil monitoring dan evaluasi didapati penilaian kinerja dan keselarasan antara kompetensi pribadi dengan tugas-tugas. Untuk itu pihak pimpinan melakukan tukar jabatan yang selaras dengan kompetensi para guru. 
c. Membantu dan memfasilitasi para guru yang belum memiliki Nomor Unik Pendidik dan Tenaga kependidikan (NUPTK) dan yang belum memperoleh sertifikat profesi guru.

d. Memberi dispensasi kepada para guru yang akan meningkatkan kapasitas diri dengan studi lanjut, serta membantu sebagian biaya studi bilamana tersedia dana ekstra.

e. Mengadakan seminar/lokakarya/pelatihan dan sejenisnya secara berkala (dua kali setahun).

\section{KESIMPULAN}

Karier adalah suatu urutan kegiatan kerja yang terpisah, tetapi berhubungan dan memberikan kesinambungan, keteraturan, dan arti bagi kehidupan seseorang. Pengembangan karier adalah suatu perencanaan karier yang diimplementasikan melalui pendidikan, pelatihan, pencarian dan perolehan kerja, serta pengalaman kerja dan semestinya dilakukan oleh setiap organisasi. Pengembangan karier memberikan manfaat baik bagi pegawai maupun bagi perusahaan, antara lain dapat menurunkan tingkat perputaran pegawai (turn-over), mendorong pertumbuhan, serta dapat meningkatkan kemampuan pegawai.

Adapun manajemen karier merupakan proses bekelanjutan dari penyiapan, penerapan dan pemantauan rencana karier yang dilakukan oleh individu. Secara luas, manajemen karier meliputi seluruh kegiatan yang berkenaan dengan pekerjaan karyawan, dimulai dari proses rekrutmen pegawai, penempatan pegawai, pengembangan pegawai, dan berakhir pada pemberhentian pegawai. Manajemen karier juga dapat dikatakan sebagai proses pengelolaan karier pegawai yang meliputi tahapan kegiatan perencanaan karier, pengembangan, dan konseling karier serta pengambilan keputusan karier.

Pengembangan karier guru pada Pesantren Darul Ihsan yang berlokasi di Kecamatan Hamparan Perak Kabupaten Deli Serdang Sumatera Utara dilakukan dalam bentuk program peningkatan karier dan pengembangan diri (personal and career advancement plan) dengan melakukan beberapa kegiatan di antaranya: 1) short course, 2) studi lanjutan (tugas/izin belajar), dan 3. in house training (IHT). Selanjutnya dilakukan kegiatan reselection (seleksi ulang) secara berkala sebagai upaya penentuan kelanjutan karier para guru melalui kegiatan monitoring yang berimplikasi adanya reposisi, mutasi, keluar/dikeluarkan, 
dan pensiun. Adapun dukungan pesantren terhadap pengembangan karier para guru bersifat bersyarat dan tanpa syarat.

\section{DAFTAR PUSTAKA}

Danang Sunyoto. (2012). Manajemen Sumber Daya Manusia. CAPS (Center for Academic Publishing Service).

Dessler, G. (1997). Human Resource Management. Prentice Hall Inc.

Greenhaus, J., Gerard A Callanan, \& Godshlik, V. M. (2000). Career Management. Dryden press.

Huberman, M., \& J, S. (2014). Qualitative Data Analysis A Methods Sourcebook (Edition 3). Sage Publications.

Mabey, C., \& Thomson, R. (1994). Developing Human Resource.

Rivai, V. (2013). Manajemen Sumber Daya Manusia Untuk Perusahaan. PT. Raja Grafindo Persada.

Rizka, Z. (2013). Sikap Terhadap Pengembangan Karir Dengan Burnout Pada Karyawan. Journal Ilmiah Psikologi Terapa, 1(2). https://doi.org/https://doi.org/10.22219/jipt.v1i2.1582

Sadili Samsudin. (2006). Manajemen Sumber Daya Manusia. Pustaka Setia.

Simamora, H. (2004). Manajemen Sumber Daya Manusia,. STAI EKPN.

Simonsen, P. (1997). Promoting a Development Culture in Your Organization Using Career Development as a Change Agent. Davies-black Publishing.

Stoner, J. A. F., \& Charles Wankel. (1986). Management (3rd editio). CV. Intermedia.

Zaini, M. F. (2019). The Implementation Of Learning Management In Class Viii Madrasa Tsanawiyah Islamiyah (MTS) YPI Batangkuis. International Conference on Islamic Educational Management (ICIEM). https:/ / scholar.google.co.id/citations?user=9xE516oAAAAJ\&hl=id\#d=gs_ md_citad\&u=\%2Fcitations\%3Fview_op\%3Dview_citation $\% 26 \mathrm{hl} \% 3 \mathrm{Did} \% 26$ user\%3D9xE516oAAAAJ\%26citation_for_view\%3D9xE516oAAAAJ\%3Au5 HHmVD_uO8C\%26tzom\%3D-420

Zaini, M. F., \& Syafaruddin, S. (2020). The Leadership Behavior of Madrasah Principals in Improving the Quality of Education in MAN 3 Medan. Jurnal Iqra': Kajian Ilmu Pendidikan, 5(2), 95-106. https://doi.org/10.25217/ji.v5i2.649 